\title{
Benign Outer Hair Sheath and Infundibulum Neoplasm
}

National Cancer Institute

\section{Source}

National Cancer Institute. Benign Outer Hair Sheath and Infundibulum Neoplasm. NCI

Thesaurus. Code C43315.

A benign neoplasm occurring in the outer hair sheath and infundibulum. 